\title{
Taxonomic Relationship between Pseudomonas perfectomarina ZoBell and Pseudomonas stutzeri
}

\author{
RAMON A. ROSSELLÓ-MORA, $†$ ELENA GARCÍA-VALDÉS, AND JORGE LALUCAT* \\ Laboratori de Microbiologia, Departament de Biologia Ambiental, Facultat de Ciències, Universitat de les \\ Illes Balears, and Institut d'Estudis Avançats (CSIC-UIB), 07071 Palma de Mallorca, Spain
}

\begin{abstract}
We clarified the taxonomic position of Pseudomonas perfectomarina ZoBell in the species Pseudomonas stutzeri. Both genotypic and phenotypic observations led us to conclude that this strain belongs to genomovar 2 of $P$. stutzeri, for which strain ATCC 17591 is the reference strain. The uncertainty about the motility of strain ZoBell was also clarified. We found that strain ZoBell is motile by means of one polarly inserted flagellum.
\end{abstract}

Strain ZoBell (= ATCC 14405) is a member of the species Pseudomonas stutzeri and among all of the pseudomonads is the strain for which the process of denitrification has been studied best (19). $P$. stutzeri is also especially interesting because of its ecological features, such as degradation of environmental pollutants and natural transformation $(3,6,9$, $10,15)$.

$P$. stutzeri ZoBell was isolated as a marine bacterium and was described by ZoBell and Upham in 1944 as "Pseudomonas perfectomarinus" (18); later, this organism became the only member of the species Pseudomonas perfectomarina (4). This strain was given species status because its phenotypic description did not warrant placement with rRNA-DNA homology group I Pseudomonas species; among all of its characteristics, its lack of flagellation was emphasized (4). It has recently been proposed that $P$. perfectomarina should be transferred to $P$. stutzeri because of the consistent agreement of the phenotypic features of these organisms. However, genotypically, $P$. perfectomarina was on the borderline of the range of DNA-DNA homology values with the type strain to be placed in the same species (5).

Our previous taxonomic studies on $P$. stutzeri revealed that the strains of this species are clustered in at least seven genomic groups that are easily distinguishable by their $\mathrm{G}+\mathrm{C}$ contents and that these taxa might constitute different species (12). However, we could not find any phenotypic characteristic that discriminates among the genomic groups, and since phenotypic properties are essential for species definition (17), we designated each of the genomic groups as a genomovar (12). Immunologic and chemotaxonomic data also confirmed the high degree of genomovar phenotypic heterogeneity (13).

Palleroni et al. (11) were the first authors to state that $P$. stutzeri might contain more than a single species on the basis of the low levels of DNA-DNA homology among their strains. This was confirmed by our characterization of the genomic structure of the species with genomovars (12). When $P$. perfectomarina was transferred to $P$. stutzeri, low levels of DNA-DNA homology with the type strain, ATCC $17588(60 \%)$, and strain DSM $50227(61 \%)$ were observed (5). If the genomovar subdivision of the species is used, this observation means that strain ZoBell does not belong to genomovar 1 (which contains the type strain) or genomovar

\footnotetext{
* Corresponding author

† Present address: Lehrstuhl für Mikrobiologie, Technische Universität München, D-80290 Munich, Germany.
}

3 (for which DSM 50227 is the reference strain), but rather belongs to one of the five other genomovars.

Genotypic studies. We performed DNA-DNA hybridization experiments with strain ZoBell to clarify its exact taxonomic position in $P$. stutzeri. Table 1 shows all of the microorganisms used in this study together with the DNADNA homology results obtained. Total DNA was isolated as described by Lind and Ursing (8). DNA was labeled with ${ }^{125} I$ by the method described by Selin et al. (14). DNA-DNA hybridization was performed by using the quantitative filter method of Tjernberg et al. (16). The differences between repeated determinations of differences in melting temperatures $\left(\Delta T_{m}\right)$ ranged from 0.1 to $0.7^{\circ} \mathrm{C}$, and the pooled standard deviation was $0.43^{\circ} \mathrm{C}$.

Our hybridization results (Table 1) showed that strain ZoBell has a $\Delta T_{m}$ of $8.0^{\circ} \mathrm{C}$ with strain ATCC 17594 (genomovar 1) and a $\Delta T_{m}$ of $5.9^{\circ} \mathrm{C}$ with strain DSM 50227 (genomovar 3). These results correspond to approximately 60 to $65 \%$ DNA relatedness (7) and are in agreement with previously reported data (5). However, strain ZoBell had a $\Delta T_{m}$ of $0.6^{\circ} \mathrm{C}$ with the reference strain of genomovar 2 , ATCC 17591. This high degree of DNA-DNA homology with ATCC 17591 clearly places strain ZoBell in genomovar 2 of $P$. stutzeri. The DNA-DNA homology values with the reference strains of the other $P$. stutzeri genomovars and with the

TABLE 1. Levels of DNA relatedness between $P$. stutzeri ZoBell and reference strains of all of the genomovars and related species, as determined by the quantitative filter method

\begin{tabular}{llccc}
\hline & DNA from: & & \multicolumn{2}{c}{$\Delta T_{m}\left({ }^{\circ} \mathrm{C}\right)$ with labeled } \\
DNA from:
\end{tabular}

${ }^{a}$ Data from reference 13 .

${ }^{b} \mathrm{ND}$, not determined.

c Data in parentheses were obtained by the hydroxyapatite method.

${ }^{d} \mathrm{~T}=$ type strain. 
TABLE 2. Biochemical properties of strain ZoBell (= ATCC $14405)$ and $P$. stutzeri genomovar 2

\begin{tabular}{lcc}
\hline Characteristic & $\begin{array}{c}\text { Reaction of strain } \\
\text { ATCC } 14405\end{array}$ & $\begin{array}{c}\% \text { of } \\
\text { genomovar 2 } \\
\text { strains positive }\end{array}$ \\
\hline Growth at: & - & 0 \\
$42^{\circ} \mathrm{C}$ & - & 0 \\
pH 6 & + & 75 \\
Use of: & - & 0 \\
Fructose & - & 100 \\
Xylose & + & 100 \\
Mannitol & - & 25 \\
Ethylene glycol & - & 0 \\
Suberate & + & 100 \\
4-Aminobutyrate & & \\
D-Malate & &
\end{tabular}

${ }^{a}$ Data based on four strains (12).

Pseudomonas mendocina and Pseudomonas aeruginosa type strains were practically identical to those observed previously when strain ATCC 17591 was labeled in hybridization assays (12).

In the first description of $P$. perfectomarina, Baumann et al. (4) calculated a $\mathrm{G}+\mathrm{C}$ content of $62 \mathrm{~mol} \%$ for strain ZoBell. This observation is in agreement with the placement of strain ZoBell in $P$. stutzeri genomovar 2, for which the mean $\mathrm{G}+\mathrm{C}$ content is $61.5 \mathrm{~mol} \%$ (12).

Phenotypic analysis. Biochemical tests were performed as previously described (12). We analyzed those phenotypic features previously shown to give the best discrimination among genomovars (12). Our results are shown in Table 2. Like all of the strains belonging to genomovar 2, strain ZoBell was able to grow on ethylene glycol and D-malate as sole carbon and energy sources and was not able to grow at $42^{\circ} \mathrm{C}$ and $\mathrm{pH} 6$; it also was not able to use xylose and 4-aminobutyrate as sole carbon and energy sources. However, in contrast to all other strains belonging to genomovar 2 , strain ZoBell was not able to use mannitol, in agreement with previously published observations (5). Like most of the genomovar 2 strains, strain ZoBell was able to grow with fructose and not able to grow with suberate as sole carbon and energy sources. All of these phenotypic observations except for the use of mannitol supported the placement of strain ZoBell in genomovar 2 when the reduced set of metabolic tests was used.

When we analyzed the phenotypic observations reported previously $(4,5)$, we also noted that the majority of the phenotypic traits observed for strain ZoBell were consistent with the overall phenotype of the four strains previously assigned to $P$. stutzeri genomovar 2 (12). Only the abovementioned inability to grow on mannitol and the inability to grow on L-isoleucine did not agree with the results observed for all of the other genomovar 2 strains, supporting the idea that phenotypic heterogeneity may be increased when new strains are assigned to any of the genomovars.

Antigenic relatedness. Antigenic relatedness between $P$. stutzeri strains was previously studied by the antigenic fingerprinting method, and we demonstrated that specificity of the polyclonal antisera obtained against whole cells was mainly determined by the lipopolysaccharide type of the cells (13). Antigenic relatedness was detected between strains belonging to the same genomovar, but only when the strains had been isolated from similar habitats (13). No immunological cross-reactions between strains ZoBell and ATCC 17591 were observed in immunofluorescence tests when antiserum against whole cells of strain ATCC 17591 was used with the polyclonal antibody S-probe. This result is consistent with previous observations, because strain ZoBell is of marine origin and the rest of the genomovar 2 strains belonging to the same serological group are clinical isolates.

Motility studies. One of the most important phenotypic traits which resulted in strain ZoBell becoming the single member of the species $\boldsymbol{P}$. perfectomarina was the consistent lack of motility (4), although the authors who first described this strain (18) stated that it was motile. When strain ZoBell was transferred to $P$. stutzeri, no flagella were detected; however, the authors presented indirect evidence that it was motile (swarming on moist plates) (5). We performed an enrichment for flagellated bacteria on semisolid tryptone agar medium ( $3.5 \mathrm{~g}$ of agar per liter) incubated at $30^{\circ} \mathrm{C}$ by using the swarming plate method $(1,2)$. Motility was observed with a Zeiss Axiophot phase-contrast optic microscope, and electron microscopy was performed by negatively staining a preparation with $1 \%$ phosphotungstic acid;

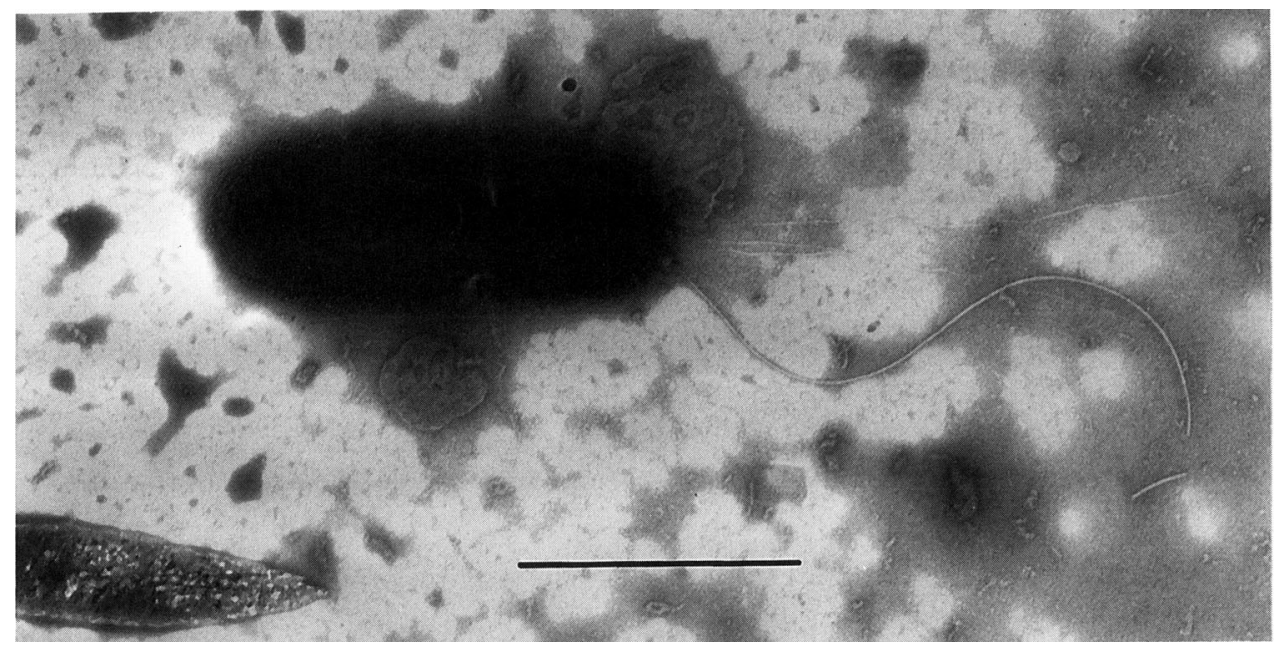

FIG. 1. Negatively stained cell of strain ZoBell with one polarly inserted flagellum. Motile cells were enriched after three passages in semisolid agar plates. Bar, $1 \mu \mathrm{m}$. 
the cells were visualized with a Hitachi model H600 transmission electron microscope by using Formvar grids.

After three passages onto fresh media we were able to obtain an enriched population containing more than $80 \%$ flagellated cells. Figure 1 shows an electron micrograph of a flagellated cell of strain ZoBell. The cells of this revertant strain are motile by means of one polarly inserted flagellum. These observations indicate that although strain ZoBell cells are clearly flagellated, nonmotile cells may have been selected in the laboratory.

In conclusion, all of our results show that strain ZoBell can be assigned to $P$. stutzeri genomovar 2 on the basis of its high degree of DNA-DNA homology with the reference strain of this genomic group and its $\mathrm{G}+\mathrm{C}$ content; also, with minor discrepancies, its phenotype is consistent with the overall genomovar 2 phenotype. Thus, $P$. perfectomarina and $P$. stutzeri genomovar 2 are synonyms. Uncertainty about motility, an important phenotypic trait of the genus Pseudomonas, has also been observed with strain ZoBell. Recently, Körner also demonstrated that strain ZoBell is motile by means of one polarly inserted flagellum (7a).

The practically identical $\Delta T_{m}$ values observed when strains ATCC 17591 and ZoBell were used as reference strains for hybridization assays confirm the subdivision of the species $P$. stutzeri into seven genomovars and also confirm that strain ZoBell was properly transferred to $P$. stutzeri on the basis of its phenotypic features.

Since genomically each of the seven genomovars of $P$. stutzeri can be considered a different species (17), further phenotypic studies may definitively allow the subdivision of $P$. stutzeri. If this occurs, genomovar 1 , with type strain ATCC 17588 , should be considered the authentic species $P$. stutzeri, and strain ZoBell and the four other strains of genomovar 2 should also have definitive and stable species status.

We thank J. Imperial, P. Kämpfer, J. Ursing, and W. Zumft for critical reading of the manuscript.

This work was supported by grants BIO 91-0659 and MAR 91-0341 from CICYT (Spain).

\section{REFERENCES}

1. Adler, J. 1966. Chemotaxis in bacteria. Science 153:708-716.

2. Armstrong, J. B., J. Adler, and M. M. Dahl. 1967. Nonchemotactic mutants of Escherichia coli. J. Bacteriol. 93:390-398.

3. Baggi, G., P. Barbieri, E. Galli, and S. Tollari. 1987. Isolation of a Pseudomonas stutzeri strain that degrades o-xylene. Appl. Environ. Microbiol. 53:2129-2132.

4. Baumann, P., R. D. Bowditch, L. Baumann, and B. Beaman. 1983. Taxonomy of marine Pseudomonas species: $P$. stanieri sp. nov.; $P$. perfectomarina sp. nov., nom. rev.; $P$. nautica; and $P$. doudoroffii. Int. J. Syst. Bacteriol. 33:857-865.

5. Döhler, K., V. A. R. Huss, and W. G. Zumft. 1987. Transfer of Pseudomonas perfectomarina Baumann, Bowditch, Baumann, and Beaman 1983 to Pseudomonas stutzeri (Lehmann and Neumann 1896) Sijderius 1946. Int. J. Syst. Bacteriol. 37:1-3.

6. García-Valdés, E., E. Cózar, R. Rotger, J. Lalucat, and J. Ursing. 1988. New naphthalene-degrading marine Pseudomonas strains. Appl. Environ. Microbiol. 54:2478-2485.

7. Johnson, J. L. 1984. Bacterial classification. III. Nucleic acids in bacterial classification, p. 8-11. In N. R. Krieg and J. G. Holt (ed.), Bergey's manual of systematic bacteriology, vol. 1 . The Williams \& Wilkins Co., Baltimore.

7a.Körner, H. Personal communication.

8. Lind, E., and J. Ursing. 1986. Clinical strains of Enterobacter agglomerans (synonyms: Enwinia herbicola, Erwinia milletiae) identified by DNA-DNA-hybridization. Acta Pathol. Microbiol. Immunol. Scand. Sect. B 94:205-213.

9. Lorenz, M. G., and W. Wackernagel. 1990. Natural genetic transformation of Pseudomonas stutzeri by sand-absorbed DNA. Arch. Microbiol. 154:380-385.

10. Obradors, N., and J. Aguilar. 1991. Efficient biodegradation of high-molecular-weight polyethylene glycols by pure cultures of Pseudomonas stutzeri. Appl. Environ. Microbiol. 57:23832388.

11. Palleroni, B. J., M. Doudoroff, R. Y. Stanier, R. E. Solánes, and M. Mandel. 1970. Taxonomy of the aerobic pseudomonads: the properties of the Pseudomonas stutzeri group. J. Gen. Microbiol. 60:215-231.

12. Rosselló, R., E. García-Valdés, J. Lalucat, and J. Ursing. 1991. Genotypic and phenotypic diversity of Pseudomonas stutzeri. Syst. Appl. Microbiol. 14:150-157.

13. Rosselló, R., E. García-Valdés, A. J. L. Macario, J. Lalucat, and E. Conway de Macario. 1992. Antigenic diversity of Pseudomonas stutzeri. Syst. Appl. Microbiol. 15:617-623.

14. Selin, Y. M., B. Harich, and J. L. Johnson. 1983. Preparation of labeled nucleic acids (nick translation and iodination) for DNA homology and rRNA hybridization experiments. Curr. Microbiol. 8:127-132.

15. Stewart, G. J., C. D. Sinigalliano, and K. A. Garko. 1991. Binding of exogenous DNA to marine sediments and the effect of DNA/sediment binding on natural transformation of Pseudomonas stutzeri strain ZoBell in sediment columns. FEMS Microbiol. Ecol. 85:1-8.

16. Tjernberg, I., E. Lind, and J. Ursing. 1989. A quantitative bacterial dot method for DNA-DNA hybridization and its correlation to the hydroxyapatite method. Curr. Microbiol. 18:7781

17. Wayne, L. G., D. J. Brenner, R. R. Colwell, P. A. D. Grimont, O. Kandler, M. I. Krichevsky, L. H. Moore, W. E. C. Moore, R. G. E. Murray, E. Stackebrandt, M. P. Starr, and H. G. Trüper. 1987. Report of the ad hoc committee on reconciliation of approaches to bacterial systematics. Int. J. Syst. Bacteriol. 37:463-464.

18. ZoBell, C. E., and H. C. Upham. 1944. A list of marine bacteria including description of sixty species. Bull. Scripps Inst. Oceanogr. Univ. Calif. 5:239-292.

19. Zumft, W. G. 1992. The denitrifying prokaryotes, p. 554-584. In A. Balows, H. G. Trüper, M. Dworkin, W. Harder, and K. H. Schleifer (ed.), The prokaryotes, 2nd ed., vol. 1. SpringerVerlag, New York. 